IGUSABDER, 11 (2020): 217-229

\title{
Hemşirelik Öğrencilerinin Mesleğe Yönelik İmaj Algıları ve Etkileyen Faktörlerin Belirlenmesi
}

\author{
Funda KARAMAN*, Sultan ÇAKMAK ${ }^{* *}$, Ayşe Nur YEREBAKAN***
}

$\ddot{O} \mathbf{z}$

Amaç: Araştırma, hemşirelik öğrencilerinin mesleki imaj algılarının ve etkileyen faktörlerin belirlenmesi amacıyla tanımlayıcı olarak planlanmıştır.

Yöntem: Çalışmanın evrenini, İstanbul ilinde bulunan özel bir üniversitede Sağlık Bilimleri Yüksekokulu'nun hemşirelik bölümünde okuyan tüm öğrenciler (N=350) oluşturmuştur. Araştırmada örneklem seçimi yapılmamış, gönüllü olarak katılmayı kabul eden 196 öğrenci araştırma kapsamına alınmıştır. Araştırma verileri "Kişisel Bilgi Formu" ve "Hemşirelik Mesleğine Yönelik İmaj Ölçeği (HMYiÖ)” kullanılarak elde edilmiştir.

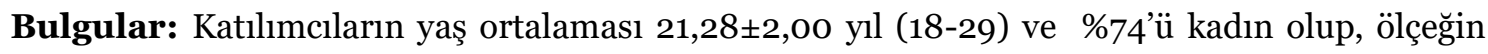
toplam puan ortalamasının 140,88 $\pm 9,46$ ( $\min 42$-max 210) olduğu bulundu. Ölçeğin alt boyutlarına bakıldığında; mesleki nitelik 43,94 $\pm 5,42$ ( $\min 11-\max 55$ ), çalışma koşulları

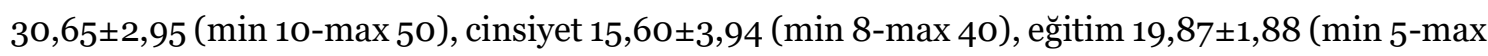

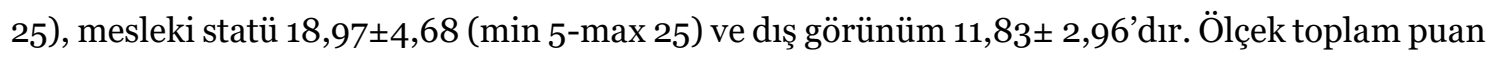
ortalaması ile cinsiyet arasında istatistiksel açıdan anlamlılık saptanmış olup kadın öğrencilerin ölçek puan ortalaması erkeklere göre yüksek bulunmuştur ( $\mathrm{p}<0.05)$.

Sonuç: Öğrencilerin hemşirelik mesleğine yönelik olarak orta düzeyde imaj algılarının olduğu belirlendi. Öğrenci hemşirelerin meslek imajını ve mesleğe karşı bakış açılarını daha fazla

\footnotetext{
Özgün Araştırma Makalesi (Original Research Article)

Geliş / Received: 14.01.2020 \& Kabul / Accepted: 27.02.2020

DOI: https://doi.org/10.38079/igusabder.674554

${ }^{*}$ Yazışma: Dr. Öğr. Üyesi, İstanbul Gelişim Üniversitesi, Sağlık Bilimleri Yüksekokulu, Hemşirelik (İngilizce), İstanbul, Türkiye, E-posta: fundakaramannn@hotmail.com ; fkaradagli@gelisim.edu.tr ORCID https://orcid.org/0000-0002-4177-9247

${ }^{* *}$ Arş. Gör., İstanbul Gelişim Üniversitesi, Sağlık Bilimleri Yüksekokulu, Hemşirelik, İstanbul, Türkiye, E-posta: sucakmak@gelisim.edu.tr ORCID https://orcid.org/oooo-0001-8505-9586 *** Arş. Gör., İstanbul Gelişim Üniversitesi, Sağlık Bilimleri Yüksekokulu, Hemşirelik (İngilizce), İstanbul, Türkiye, E-posta: anyerebakan@gelisim.edu.tr ORCID https://orcid.org/o000-00034446-5785
} 
geliştirmek için eğitim sürecinde profesyonelliğin benimsetilmesi ve mesleki donanımlarının arttırılması sağlanmalıdır.

Anahtar Sözcükler: Meslek imajı, hemşirelik, öğrenci.

Professional Image Perceptions of Nursing Students and Determining Affecting Factors

\begin{abstract}
Aim: The research was planned descriptively to determine the nursing students' perceptions of professional image and the affecting factors.

Method: The population of the study was composed of all students $(\mathrm{N}=350)$ studying in the Nursing Department of the School of Health Sciences at a private university in Istanbul. In the research, sample selection was not made and 196 students who voluntarily accepted to participate were included in the research. The data of the study was collected using "Personal Information Form" and "Scale for the Image of Nursing Profession".

Results: The mean age of the students participating in the study was $21,28 \pm 2,00$ years old (1829 ) and $74 \%$ of them were female, and the mean of scale was $140,88 \pm 9,46$. When the subscales of the scale are analyzed; professional qualities 43,94 \pm 5,42 ( $\min 11$-max 55), working conditions $30,65 \pm 2,95$ ( $\min 10-\max 50$ ), gender 15,60 $\pm 3,94$ ( $\min 8$-max 40), education 19,87 $\pm 1,88$ (min 5 -max 25), professional status $18,97 \pm 4,68$ ( $\min 5$-max 25) and appearance was $11.83 \pm 2.96$. A statistically significant difference was found between the scale total score average and the gender of the student. The average score of female students was higher than others $(\mathrm{p}<0.05)$.

Conclusion: It was determined that the students had medium level image perceptions about the nursing profession. In order to further develop the professional image and perspective of the student nurses, it should be provided that professionalism is adopted in the education process and their professional competence is improved.
\end{abstract}

Keywords: Professional image, nursing, student.

\title{
Giriş
}

İmaj, bir kimsenin, topluluğun ya da kurumun kendisi ile ilgili oluşturmak istediği veya başkalarında bıraktığı izlenim olarak tanımlanan bir kavramdır ${ }^{1}$. Bir profesyonel grubun toplum tarafından değerlendirilmesi sonucunda yaygın biçimde kabul edilen değerler ise meslek imajını oluşturur ${ }^{1-3}$. Kişinin mesleki yaşamında ve sosyal çevresinde kendisini ne şekilde gördüğü, başka insanlar tarafından nasıl görülmek istediği mesleksel imajı 
etkilemektedir4 ${ }^{4}$ Bir meslekle ilgili kabul edilen değer ve statü, çalışanların toplumdaki imajıyla şekillenir ve meslek üyeleri için kabul görülen bu değerler oldukça önemlidir ${ }^{1,3}$. Hemşire; bireyin, ailenin ve toplumun sağlığını korumak için fiziksel, ruhsal ve sosyal yönden gereksinimleri belirleyen, karşılayan ve gerekli bakımı veren profesyonellerdir. Sağlığın korunması ve sürdürülmesinde önemli sorumlulukları olan hemşirelerin, bu sorumlulukları gerçekleştirdikleri süreç içerisinde toplum tarafından oluşan mesleki imajları ve algıları vardır5.

Hemşirelik bakımı, günümüzde başarılı sağlık bakımının oldukça önemli bir belirleyicisidir. Hemşireler sağlığın sürdürülmesinde oldukça önemli sorumluluklar yerine getiriyor olsa da toplumsal ve mesleki imaj yönünden yeterli değeri görememiştir. Hemşirelik mesleğinin toplum içerisindeki saygınlığını yükseltmek, çalışma kalitesini ve çalışan hemşirelerin memnuniyetini arttırmak için hemşirelik imajı kavramı üzerinde durulmalıdir 6-8.

Hemşirelerin çalışma hayatlarındaki memnuniyetinin, mesleki başarılarının ve etkinliklerinin artmasında mesleğin olumlu yönde bir imaja sahip olması oldukça önemlidir ${ }^{-11}$. Hemşirelik mesleğinin gelişmesi, toplumsal ve mesleki imajının değerinin artmasında mesleği seven, mesleğin gerektirdiği sorumlulukların bilincinde; bilgi, beceri sahibi olan hemşirelere gereksinim vardır. Geleceğin hemşireleri olmaya aday lisans öğrencilerinin mesleğe yönelik düşünceleri ve imaj algıları bu gereksinimlerin karşılanmasında oldukça önemlidir ${ }^{12}$.

Lisans eğitiminde profesyonelliğin öğrencilere kazandırılması için, mesleğe yönelik algısal farkındalık oluşturmalarına ek olarak mesleki imaj konusunda da olumlu yönde düşünceler geliştirmiş olmaları gerekir ${ }^{13,14}$. Öğrencilerin hemşirelik mesleğine yönelik algılarının oluşumunda, mesleğe ve içerdiği uygulamalara yönelik hisleri, düşünceleri ve aldıkları hemşirelik eğitimi oldukça etkilidir¹5. Öğrencilerin hemşirelik mesleğine ve imajına dair olumsuz algıları olması, meslek içerisinde gönülsüz çalışmalarına, hızlı tükenmişliğe ve işten ayrılmayı istemelerine sebep olacaktır ${ }^{16-19}$. Hemşirelik öğrencilerinin mesleki imaj algılarının ve etkileyen faktörlerin belirlenmesi amacıyla bu çalışma yapılmıştır. 


\section{Gereç ve Yöntem}

\section{Araştırmanın Evren ve Örneklemi}

Tanımlayıcı olan araştırmanın evrenini, Özel bir Üniversite'nin Sağlık Bilimleri Yüksekokulu'nun Hemşirelik Bölümünde, 2018-2019 ylllarında okuyan tüm öğrenciler $(\mathrm{N}=350)$ oluşturmuştur. Çalışmada örneklem seçimi yapılmamış, ulaşılabilen ve çalışmaya katılmayı kabul eden toplam 196 öğrenci çalışmaya dahil edilmiş ve evrenin \%56'sına ulaşılmıştır.

\section{Araştırma Soruları}

1. Öğrencilerin mesleğe yönelik imaj algı düzeyleri nasıldır?

2. Öğrencilerin mesleki imaj algı düzeylerini etkileyen faktörler nelerdir?

\section{Verilerin Toplanması}

Araştırma verilerinin toplanmasından önce ilgili üniversitenin etik kurulundan 17.04.2018 tarih ve 2018/9 sayılı yazı ile onay alınmış ve araştırmaya katılmayı kabul eden öğrencilere çalışma hakkında bilgi verildikten sonra hem yazılı hem de sözlü onamları alınmıştır.

Veriler, "Kişisel Bilgi Formu" ve "Hemşirelik Mesleğine Yönelik İmaj Ölçeği (HMYİÖ)" kullanılarak toplanmıştır.

\section{Kişisel Bilgi Formu}

Öğrencilerin sosyodemografik özelliklerini (yaş, cinsiyet, sınıf, mezun olunan lise, anne ve baba eğitim durumu, en uzun süre yaşanılan yer, gelir düzeyi, hemşirelik bölümünü isteyerek seçme durumu, hemşirelik bölümünü tercih etme sırası, mezuniyet sonrası hemşireliği yapmayı isteme durumu, mesleği seçmede aile etkisi) kapsayan toplam 12 soru yer almaktadır. Anketin doldurulması 15-20 dk sürmüştür.

\section{Hemşirelik Mesleğine Yönelik İmaj Ölçeği}

Ölçek, Dost ve Bahçecik tarafından geliştirilmiş olup, 42 maddeden oluşan 1-5 arası puanlanan likert tipi bir ölçektir. Ölçek 6 alt boyut içermekte olup, bu alt boyutlar; mesleki nitelik (11 madde), çalışma koşulları (10 madde), cinsiyet (8 madde), eğitim (5 
madde), mesleki statü (5 madde) ve dış görünümden (3 madde) oluşmaktadır. Ölçeğin Cronbach alfa katsayısı 0,97 bulunmuş olup, ölçeğin değerlendirilmesinde toplam 15 madde $(8,14,15,17,18,20,21,22,23,24,25,26,28,29$ ve 31) negatif yönde puanlanmaktadır. Ölçekten alınabilecek en düşük puan 42 en yüksek puan 210 olup, 4275 çok zayıf, 76-109 zayıf, 110-143 orta, 144-177 iyi ve 178-210 ise çok iyi imaj algısının olduğunu belirtmektedir. Ölçekten alınan puan yükseldikçe imaj algısı da olumlu olarak $\operatorname{artmaktadir}^{20}$.

\section{Verilerin Analizi}

Çalışmanın analizi bilgisayar ortamında SPSS ile yapılmış olup, tanımlayıcı istatistikler için aritmetik ortalama, standart sapma, frekans ve yüzde değerleri kullanılmıştır. Bağımsız değişkenler ile bağımlı değişkenler arasındaki ilişkiyi test edebilmek için öncelikle verilerin normal dağılım gösterip göstermediğine bakılmış, KolmogorovSmirnov p değerinin o.o5'ten küçük olması nedeniyle MannWhitney U ve Kruskall Wallis analizleri yapılmıştır. Sonuçların değerlendirilmesinde $\mathrm{p}<0,05$ istatistiksel olarak anlamlı kabul edilmiştir.

\section{Bulgular}

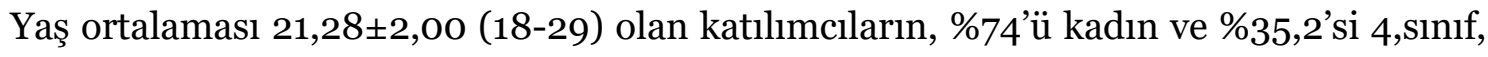
\%13,8’i Sağlık Meslek Lisesinden mezun, çoğu (\%98) zamanını il/ilçede geçirmiş ve \%59,2'sinin gelir durumu orta düzeydedir. Öğrencilerin annelerinin \%8,2'si ve babalarının \% 13,8’i üniversite mezunudur. Katılımcıların ailedeki sağlık mensubu varlığı oranı \% 34,2 olarak bulunmuş olup, \%77,6'sı hemşirelik bölümünü isteyerek seçmiş, \%91,8’i hemşirelik bölümünü ilk sıralarda tercih etmiş, \%40,3’ü bu seçimi yaparken kendi kararları olduğunu belirtmişlerdir. Ayrıca öğrencilerin çoğunun (\%74) mezuniyet sonrası hemşirelik mesleğini yapmayı düşündükleri saptanmıştır (Tablo 1).

Tablo 1. Öğrencilerin Kişisel Özellikleri (n=196)

\begin{tabular}{|l|l|l|l|}
\hline & Kişisel Özellikler & $\mathbf{n}$ & $\mathbf{\%}$ \\
\hline Cinsiyet & Kız & 145 & 74,0 \\
& Erkek & 51 & 26,0 \\
\hline \multirow{3}{*}{ Sinıf } & 1. sinıf & 28 & 14,3 \\
& 2. sinıf & 68 & 34,7 \\
& 3. sinıf & 31 & 15,8 \\
& 4. sinıf & 69 & 35,2 \\
\hline
\end{tabular}




\begin{tabular}{|c|c|c|c|}
\hline Mezun Olduğu Okul & $\begin{array}{l}\text { Düz/Teknik Lise } \\
\text { Sağlık Meslek Lisesi } \\
\text { Anadolu Lisesi }\end{array}$ & $\begin{array}{l}92 \\
27 \\
77\end{array}$ & $\begin{array}{l}46,9 \\
13,8 \\
39,3\end{array}$ \\
\hline Annenin Eğitim Durumu & $\begin{array}{l}\text { Okuryazar değil } \\
\text { İlkokul } \\
\text { Ortaokul } \\
\text { Lise } \\
\text { Üniversite }\end{array}$ & $\begin{array}{l}14 \\
65 \\
54 \\
47 \\
16\end{array}$ & $\begin{array}{l}7,1 \\
33,2 \\
27,6 \\
24,0 \\
8,2\end{array}$ \\
\hline Babanın Eğitim Durumu & $\begin{array}{l}\text { Okuryazar değil } \\
\text { İlkokul } \\
\text { Ortaokul } \\
\text { Lise } \\
\text { Üniversite }\end{array}$ & $\begin{array}{l}4 \\
52 \\
57 \\
56 \\
27\end{array}$ & $\begin{array}{l}2,0 \\
26,5 \\
29,1 \\
28,6 \\
13,8\end{array}$ \\
\hline En Uzun Süre Yaşanılan Yer & $\begin{array}{l}\text { Köy/Belde } \\
\text { İl/İlçe }\end{array}$ & $\begin{array}{l}4 \\
192\end{array}$ & $\begin{array}{l}2,0 \\
98,0\end{array}$ \\
\hline Gelir Düzeyi & $\begin{array}{l}\text { Düşük } \\
\text { Orta } \\
\text { İyi }\end{array}$ & $\begin{array}{l}9 \\
116 \\
71\end{array}$ & $\begin{array}{l}4,6 \\
59,2 \\
36,2\end{array}$ \\
\hline $\begin{array}{l}\text { Ailede Sağlık Mensubu Olma } \\
\text { Durumu }\end{array}$ & $\begin{array}{l}\text { Var } \\
\text { Yok }\end{array}$ & $\begin{array}{l}67 \\
129\end{array}$ & $\begin{array}{l}34,2 \\
65,8\end{array}$ \\
\hline $\begin{array}{l}\text { Hemşirelik Bölümünü } \\
\text { İsteyerek Seçme Durumu }\end{array}$ & $\begin{array}{l}\text { Evet } \\
\text { Hayır }\end{array}$ & $\begin{array}{l}152 \\
44\end{array}$ & $\begin{array}{l}77,6 \\
22,4\end{array}$ \\
\hline $\begin{array}{l}\text { Hemşirelik Bölümünü Tercih } \\
\text { Etme Sırası }\end{array}$ & $\begin{array}{l}\text { 1-10. Sira } \\
11-24 . \text { Sira } \\
25-30\end{array}$ & $\begin{array}{l}180 \\
11 \\
5\end{array}$ & $\begin{array}{l}91,8 \\
5,6 \\
2,6\end{array}$ \\
\hline $\begin{array}{l}\text { Mezuniyetten Sonra } \\
\text { Hemşirelik Mesleğini Yapmayı } \\
\text { İsteme Durumu }\end{array}$ & $\begin{array}{l}\text { İstiyorum } \\
\text { İstemiyorum } \\
\text { Kararsızım }\end{array}$ & $\begin{array}{l}145 \\
6 \\
45\end{array}$ & $\begin{array}{l}74,0 \\
3,1 \\
23,0\end{array}$ \\
\hline $\begin{array}{l}\text { Mesleği Seçmede Ailenin } \\
\text { Etkisi }\end{array}$ & $\begin{array}{l}\text { Baskıcı davrandılar } \\
\text { Seçimi bana } \\
\text { bıraktılar } \\
\text { Olumlu davrandılar } \\
\text { Etkilemediler }\end{array}$ & $\begin{array}{l}24 \\
79 \\
67 \\
26\end{array}$ & $\begin{array}{l}12,2 \\
40,3 \\
34,2 \\
13,3\end{array}$ \\
\hline
\end{tabular}

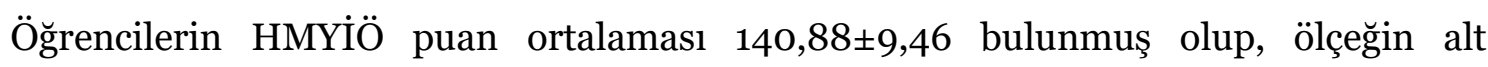

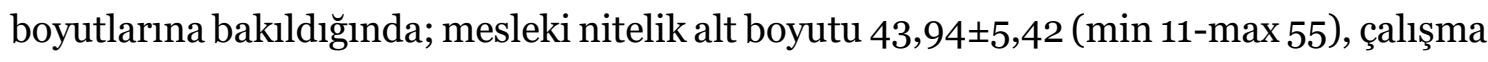

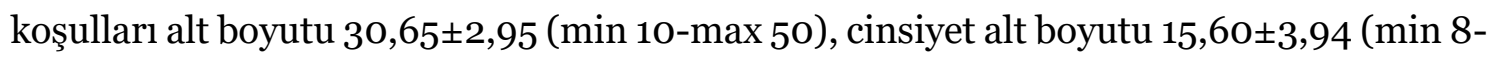
max40), eğitim alt boyutu $19,87 \pm 1,88$ (min 5 -max 25), mesleki statü alt boyutu 


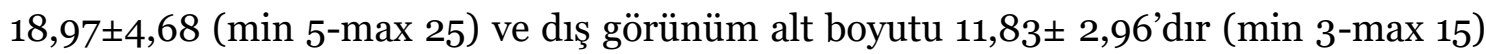
(Tablo 2).

Tablo 2. Öğrencilerin Hemşirelik Mesleğine Yönelik İmaj Ölçeği ve Alt Ölçek Boyut Puan Ortalamalarının Dağılımı (n=196)

\begin{tabular}{|l|l|}
\hline Ölçek ve alt boyutları & Puan ortalamaları (Ort \pm SS) \\
\hline Mesleki nitelik & $43,94 \pm 5,42$ \\
\hline Çalışma koşulları & $30,65 \pm 2,95$ \\
\hline Cinsiyet & $15,60 \pm 3,94$ \\
\hline Eğitim & $19,87 \pm 1,88$ \\
\hline Mesleki statü & $18,97 \pm 4,68$ \\
\hline Dış görünüm & $11,83 \pm 2,96$ \\
\hline Toplam Ölçek Puan & $140,88 \pm 9,46$ \\
\hline
\end{tabular}

HMYİÖ puan ortalamaları ile öğrencilerin bireysel özellikleri karşılaştırıldı ̆̆ında; bulundukları sınıf düzeyi, gelir durumu, mezun olduğu okul, aile etkisi, ailede sağlık mensubu olma durumu, hemşirelik bölümünü isteyerek seçme durumu, mezuniyetten sonra hemşirelik mesleğini yapmayı isteme durumu ile ölçeğin toplam puan ortalamaları arasında istatistiksel bir anlamlılık olmadığı bulunmuştur (p>0,05) (Tablo 3). Ölçeğin toplam puan ortalaması ve cinsiyet arasında istatistiksel açıdan anlamlı bulunmuş olup kadın öğrencilerin puan ortalaması erkeklere göre daha yüksektir ( $\mathrm{p}<0,05)$ (Tablo 3). 
Tablo 3. Öğrencilerin HMYï̈ Toplam Puan Ortalamaları ile Bazı Kişisel Özelliklerinin Karşılaştırılması (n=196)

\begin{tabular}{|c|c|c|c|c|}
\hline Bireysel Özellikler & & $\begin{array}{l}\text { Sura } \\
\text { Ort, }\end{array}$ & $\mathrm{X}^{2} / \mathrm{Z}$ & $\mathbf{P}$ \\
\hline Cinsiyet & $\begin{array}{l}\text { Kadın } \\
\text { Erkek }\end{array}$ & $\begin{array}{l}104,48 \\
81,50\end{array}$ & $Z=-2,49$ & $0,01^{*}$ \\
\hline Sinifi & $\begin{array}{l}\text { 1, sinif } \\
2, \text { sinif } \\
\text { 3, sinif } \\
\text { 4, sinif }\end{array}$ & $\begin{array}{l}95,13 \\
103,46 \\
100,23 \\
94,21\end{array}$ & $\chi^{2}=1,04$ & 0,79 \\
\hline Mezun Olduğu Okul & $\begin{array}{l}\text { Düz/Teknik Lise } \\
\text { Sağllk Meslek Lisesi } \\
\text { Anadolu Lisesi }\end{array}$ & $\begin{array}{l}99,21 \\
103,24 \\
95,99\end{array}$ & $x^{2}=0,35$ & 0,83 \\
\hline Gelir Düzeyi & $\begin{array}{l}\text { Düşük } \\
\text { Orta } \\
\text { İyi }\end{array}$ & $\begin{array}{l}115,61 \\
93,29 \\
104,84\end{array}$ & $x^{2}=2,68$ & 0,26 \\
\hline $\begin{array}{l}\text { Ailede Sağllk Mensubu } \\
\text { Olma Durumu }\end{array}$ & $\begin{array}{l}\text { Var } \\
\text { Yok }\end{array}$ & $\begin{array}{l}89,93 \\
102,95\end{array}$ & $Z=-1,52$ & 0,12 \\
\hline $\begin{array}{l}\text { Hemşirelik Bölümünü } \\
\text { İsteyerek Seçme Durumu }\end{array}$ & $\begin{array}{l}\text { Evet } \\
\text { Hayır }\end{array}$ & $\begin{array}{l}99,39 \\
95,41\end{array}$ & $\mathrm{Z}=-0,41$ & 0,68 \\
\hline $\begin{array}{l}\text { Mezuniyetten Sonra } \\
\text { Hemşirelik Mesleğini } \\
\text { Yapmayı İsteme Durumu }\end{array}$ & $\begin{array}{l}\text { İstiyorum } \\
\text { İstemiyorum } \\
\text { Kararsızım }\end{array}$ & $\begin{array}{l}99,60 \\
102,58 \\
94,16\end{array}$ & $x^{2}=0,36$ & 0,83 \\
\hline $\begin{array}{l}\text { Mesleği Seçmede Ailenin } \\
\text { Etkisi }\end{array}$ & $\begin{array}{l}\text { Baskıcı davrandılar } \\
\text { Seçimi bana bıraktılar } \\
\text { Olumlu davrandılar } \\
\text { Etkilemediler }\end{array}$ & $\begin{array}{l}81,46 \\
102,49 \\
103,28 \\
89,79\end{array}$ & $x^{2}=3,65$ & 0,30 \\
\hline $\begin{array}{l}\text { Hemşirelik Bölümünü } \\
\text { Tercih Etme Sirası }\end{array}$ & $\begin{array}{l}\text { 1-10, Sira } \\
11-24, \text { Sira } \\
25-30\end{array}$ & $\begin{array}{l}98,98 \\
94,14 \\
90,90\end{array}$ & $x^{2}=0,13$ & 0,91 \\
\hline
\end{tabular}

*p<0,05 (Mann Whitney U ve Kruskall Wallis testi kullanılmıştır.) 
Ölçeğin tüm alt boyutları ile katılımcıların ailede sağlık mensubu olma durumu, mezun olduğu okul, mesleği seçmede ailenin etkisi ve hemşirelik bölümünü tercih etme sırası karşılaştırıldığında istatistiksel açıdan anlamlılık bulunmamıştır ( $p>0,05)$.

Öğrencilerin sınıf düzeyi ile HMYIÖ alt boyutları ile karşılaştırıldığında "mesleki nitelik" alt boyut puanı ile "çalışma koşulları" alt boyutları arasında istatistiksel olarak anlamlı farklılık saptanmış olup ( $\mathrm{p}<0,05)$, son sınıfta bulunan öğrencilerin mesleki nitelik alt boyutu diğerlerine oranla daha yüksek bulunurken, çalışma koşulları alt boyutu daha düşük bulunmuştur.

Hemşirelik öğrencilerinin mesleği isteyerek seçme ve mezuniyet sonrası hemşirelik mesleğini yapmayı isteme durumu ile HMYİÖ alt boyutları karşılaştırıldı̆̆ında sadece "mesleki nitelik" alt boyut puanı istatistiksel açıdan anlamlı olup ( $<<0,05)$, "mesleği isteyerek seçmeyenlerde" ve "mezuniyet sonrası hemşirelik mesleğini yapmak istemiyorum" yanıtı verenlerde mesleki nitelik alt boyutu daha yüksek bulunmuştur.

Hemşirelik öğrencilerinin HMYIÖ “çalışma koşulları” alt boyut puanları, katılımcıların cinsiyetlerine göre karşılaştırıldığında, istatistiksel anlamlılı bulunmuş $(p<0,05)$, cinsiyeti kadın öğrencilerin puanlarının ortalaması erkeklere oranla yüksek bulunmuştur. Diğer alt boyutlar ile aralarında istatistiksel açıdan anlamlı bir fark saptanmamıştır ( $\mathrm{p}>0,05)$.

\section{Tartışma}

Ölçekten alınabilecek puan aralığı 42-210 arasındadır. Yapılan bu çalışmada HMYiÖ puan ortalaması 140,88 $\pm 9,46$ olarak orta düzeyde bulunmuştur, Özkan ve arkadaşları 2017 yılında yaptıkları çalışmada puan ortalamasını orta düzeyde $(142,2 \pm 10,4)$ bulmuşlardır ${ }^{21}$. Kadın öğrencilerin HMYï̈ puan ortalamasının istatistiksel olarak anlamlı çıktı̆̆ı bu çalışmada erkek öğrencilerin sayıca azlı̆̆ına rağmen HMYiÖ puan ortalamalarının kadın öğrencilere yakın olduğu görülmüsstür. Erkek öğrencilerin zamanla hemşirelik mesleğine yönelik algılarının değiştiği ve hemşireliği sadece kadın mesleği olarak görmedikleri son yllardaki çalışmalarda görülmüştür. Koç ve arkadaşlarının 60 erkek öğrenci üzerinde yaptığı çalışmada öğrencilerin \%80’ninin hemşirelik mesleğinde cinsiyet ayrımı olmaması gerektiğini, \%80'ninin erkek hemşire sayısının artması ile toplumda hemşirelik mesleğine yönelik önyargıların kalkacağını ifade etmişlerdir²2. Ünver ve Avcıbaşı hemşirelik bölümünde okuyan erkek öğrencilerin 
sosyal çevrelerinde yaşadıkları sorunları incelemiş ve öğrencilerin \%74,2'sinin hemşirelik bölümünü okumaları nedeniyle herhangi bir sorun yaşamadıklarını bildirmişlerdir²3. HMYIOÖ alt boyutları incelendiğinde ise "mesleki nitelik" alt boyutu en yüksek puan ortalamasına sahiptir. Öğrencilerin aldıkları eğitim ve uygulama deneyimleri sonucunda zaman içerisinde hemşirelik mesleğinin sağlık ekibi içerisindeki yerini ve önemli sorumluluklarını keşfettiğini, hemşirelik mesleğinin kişiye zeka ve beceri ile yaratıcı olma gibi karakteristik özelliklere sahip olma zorunluluğunu yüklediğini, çalışma süresince özverili ve sabırlı olmanın öneminin farkına vardıklarını ve çalışma hayatının dışında da sorumluluk hissettiklerini göstermektedir. "Mesleki nitelik" alt boyutunun son sinıflarda daha yüksek puan ortalamasına sahip olması bu düşüncelerin tecrübe ile yerleştiğini göstermektedir. Öğrencilerin sınıf düzeyi ile HMYIÖ alt boyutları karşılaştırıldığında "çalışma koşulları" alt boyut puanının son sınıf öğrencilerinde en düşük puan ortalamasına sahip olduğu belirlenmiştir. "Çalışma koşulları" alt boyut puanının son sınıf öğrencilerinde düşük çıkmasının; eğitim gördükleri süreç içerisindeki uygulamalarda edindikleri tecrübeyle, hemşirelik mesleğinin çalışma koşullarını, sorumluluklarını, iş yüklerini, çalışma saatlerinin fazla olduğunu ve zorlu süreçler içerdiğini fark etmeleri ile bağlantılı olduğu düşünülmektedir. Yapılan bir çalışmada hemşirelik öğrencilerinin bölümü istemeden seçme ve öğrenim görme, iş yükü, sosyal etkinliklere vakit ayıramama, hastalara bakım verme, hastanedeki tehlike ve riskler nedeniyle mesleğe yönelik olumlu düşünceleri olmadığı ve tükenmişlik yaşayabileceği belirtilmiştir²4. Her ne kadar hemşirelerin çalışma alanının geniş olduğu düşünülse de iş tanımındaki belirsizlikler ve karşılığındaki ücretin düşük olması son sınıf öğrencilerinin hemşirelerin çalışma koşullarına dair olumsuz yönde algı geliştirdiklerini göstermektedir.

Karaöz (2002), hemşirelerin hoşgörülü, empati yapabilen ve bilgili kişiler olmaları gerektiğini belirtirken, Andsoy ve arkadaşları (2012) da temiz, güler yüzlü ve alçak gönüllülük gibi özelliklerin hemşirelerde mutlaka bulunması gerektiğini vurgulamıştır25,26. Özdelikara ve arkadaşları (2015) hemşirelik imajını araştırmış ve hemşirelik öğrencilerinin \%28,8’i merhamet duygusunun hemşirelerde bulunması gereken en önemli özelliklerden biri olduğunu ifade etmiştir5. Bu özellikleri kapsayan “dış görünüm” alt boyut puanının yapılan çalışmada HMYIÖ alt boyutları arasında diğer alt boyutlara göre daha düşük olduğu görülmüştür. Öğrencilerin hastanedeki 
deneyimleri ve gözlemleri sırasında hemşirelerin sözlü iletişim ve beden dilini kullanma konusunda yeterince olumlu etki bırakmadığı düşünülmektedir.

\section{Sonuç ve Öneriler}

Öğrencilerin hemşirelik mesleğine yönelik olarak orta düzeyde imaj algılarının olduğu saptanmıştır. Öğrenci hemşirelerin mesleğe karşı imajını ve bakış açılarını daha fazla geliştirmek için eğitim sürecinde profesyonelliğin benimsetilmesi ve mesleki donanımlarının arttırılması sağlanmalıdır. Öğrencilikte benimsetilecek olan bu algı mesleğin daha fazla profesyonelleşmesine, ilerlemesine katkı sağlayacak ve mesleki imajı da artıracaktır.

\section{KAYNAKLAR}

1. Emiroğlu N. Sağlık personelinin ve toplumun hemşirelik imajı. Hemşirelik Araştırma Dergisi. 2000;2(1):9-18.

2. Özcan A, Özgür H. Hemşirelerin mesleki benliklerini algılayışları. In: Erefe İ, ed. II. Ulusal Hemşirelik Kongresi Bildiri Kitabı. İzmir: Ege Üniversitesi Basımevi; 1990:226-32.

3. Özsoy SA. Toplumda hemşirelik imajının belirlenmesi. Ege Üniversitesi Hemşirelik Yüksekokulu Dergisi. 2000;16(2-3):1-19.

4. Bromley DB. Reputation, Image and Impression Management. England: John Willey \& Sons Ltd,; 1993.

5. Özdelikara A, Boğa NM, Çayan N. Hemşirelik öğrencilerine ve sağlık alanı dışındaki öğrencilere göre hemşirelik imajı. Düzce Üniversitesi Sağlık Bilimleri Enstitüsü Dergisi. 2015;5(2):1-5.

6. Dağlı R, Çakırcalı E, Girgeç S, Çalışkan İ. Hemşirelik imajı. In: 13. Ulusal Hemşirelik Kongresi; 1-3 Mayıs 2014; Trabzon, Türkiye.

7. Ertem G, Dönmez YC, Oksel E. Günlük gazetelerde hemşirelik haberlerinin incelenmesi. Maltepe Üniversitesi Hemşirelik Bilim ve Sanatı Dergisi. 2009;2(2):70-5. 
8. Khorshid L, Eşer İ, Çınar Ş, Arslan GG. Öğrencilerin toplumdaki hemşirelik imajına ilişkin görüşleri. Ege Üniversitesi Hemşirelik Yüksekokulu Dergisi. 2005;21(2):581-8.

9. Gul R. The image of nursing from nurses and non nurses perspectives in Pakistan first. Independent Nursing Journal of Pakistan. 2008;1(2):1-16.

10. Çıtak Tunç G, Akansel N, Özdemir A. Hemşirelik ve sağlık memurluğu öğrencilerinin meslek seçimlerini etkileyen faktörler. Maltepe Üniversitesi Hemşirelik Bilim ve Sanat Dergisi. 2010;3(1):24-31.

11. Finkelman A, Kenner C. The image of nursing: what it is and how it needs to change. In: Harvey A, Bempkins S, eds. Professional Nursing Concepts. 2nd ed. Burlington: Jones \& Bartlett L; 2013:85-109.

12. Korkmaz F, Görgülü S. Hemşirelerin meslek ölçütleri bağlamında hemşireliğe ilişkin görüşleri. Sağlık Bilimleri Fakültesi Hemşirelik Dergisi. 2010;17(1):1-17.

13. Björkström ME, Athlin EE, Johansson IS. Nurses' development of professional self-from being a nursing student in a baccalaureate programme to an experienced nurse. Journal of Clinical Nursing . 2008;17(10):1380-1391.

14. Özmen D, Çetinkaya A. Hemşirelik son sınıf öğrencilerinin mesleki algılarına yönelik nitel bir çalışma. Turkish Journal of Research \& Development in Nursing. 2016;18(1):40-52.

15. Çınar Yücel Ş, Güler E, Eşer İ, Khorshid L. İki farklı eğitim sistemi ile öğrenim gören hemşirelik son sınıf öğrencilerinin hemşirelik mesleğini algılama durumlarının karşılaştırılması. Ege Üniversitesi Hemşirelik Yüksek Okulu Dergisi. 2011;27(3):1-8.

16. Slatyer S, Coventry LL, Twigg D, Davis S. Professional practice models for nursing: a review of the literature and synthesis of key components. Journal of Nursing Management. 2016;24(2):139-150.

17. Andrews LD. Current Image of Professional Nursing. www.rsu.edu.tr. Yayınlanma tarihi 2007. Erişim tarihi 17 Ocak 2019. 
18. Hung CA, Wu PL, Liu NY, Hsu WY, Lee BO, Pai HC. The effect of genderfriendliness barriers on perceived image in nursing and caring behaviour among male nursing students. Journal of Clinical Nursing . 2019;28(9-10):1465-1472.

19. Cheng $\mathrm{CH}$. Perceptions of nursing image held by third and fourth-year baccalaureate nursing students and related factors. The Journal of Nursing. 2016;63:91-102.

20. Dost A, Bahçecik AN. Hemşirelik mesleğine yönelik imaj ölçeği geliştirilmesi. JAREN. 2015;1(2):51-59.

21. Özkan Z, Ünver S, Avcıbaşı İM, Semerci R, Fındık Ü. Bir grup hemşirelik öğrencisinin mesleğe yönelik imaj algısı. Hemşirelikte Araştırma Geliştirme Dergisi. 2017;19(1):38-47.

22. Koç Z, Bal C, Sağlam Z. Erkek öğrenci hemşirelerin hemşirelik mesleğini algılama durumlarının belirlenmesi. Maltepe Üniversitesi Hemşirelik Bilim ve Sanatı Dergisi. 2010; (Sempozyum Özel Sayısı):318-323.

23. Ünver S, Avcıbaşı IM, Özkan ZK, Motör D. Hemşirelik bölümünde okuyan erkek öğrencilerin sosyal çevrelerinde yaşadıkları sorunlar. İnsan ve Toplum Bilimleri Araştırmaları Dergisi. 2016;5(6):1636-1648.

24. Arkan G, Ordin YS, Haney MÖ. Hemşirelik öğrencilerinin mesleki değerleri ve tükenmişlik düzeyi arasındaki ilişki. ACU Sağlık Bilimleri Dergisi. 2019;10(3): 443-450.

25. Karaöz S. Hemşirelik öğrencilerinin eğitimleri sırasında mesleğe ilişkin algılarındaki değişimin incelenmesi: hemşireliğe giriş dersinin bu değişimdeki rolü. Cumhuriyet Üniversitesi Hemşirelik Yüksekokulu Dergisi. 2002;6(2):1020.

26. Andsoy I, Güngör T, Bayburtoğlu T. Karabük üniversitesi sağllk yüksekokulu öğrencilerinin hemşireliği tercih etme nedenleri ve mesleğin geleceği ile ilgili görüşleri. Balıkesir Sağlık Bilimleri Dergisi. 2012;1(1):124-130. 